Jurnal e-GiGi (eG), Volume 2, Nomor 2, Juli-Desember 2014

\title{
GAMBARAN TINGKAT KEPUASAN PASIEN TERHADAP PERAWATAN GIGI DAN MULUT DI PUSKESMAS BAHU
}

\author{
${ }^{1}$ Mariane Sembel \\ ${ }^{2}$ Henry Opod \\ ${ }^{3}$ Bernart S. P. Hutagalung
}

\author{
${ }^{1}$ Kandidat Skripsi Program Studi Pendidikan Dokter Gigi Fakultas Kedokteran \\ Universitas Sam Ratulangi Manado \\ ${ }^{2}$ Fakultas Kedokteran Universitas Sam Ratulangi Manado \\ ${ }^{3}$ Program Studi Pendidikan Dokter Gigi Fakultas Kedokteran \\ Universitas Sam Ratulangi Manado \\ Email: marianesembel@ymail.com
}

\begin{abstract}
Patient satisfaction with dental care is a comparison between the perceptions of care received by expectations before getting treatment. The study in Bahu Health centers based on seven dimensions of service quality is the guarantee, empathy, reliability, responsiveness, physical appearance, medical services and professionalism using Likert scale. The study was descriptive with a sample of 48 people. How sampling is total sampling. Results showed patient satisfaction with dimensions of guarantee $80,9 \%$ very satisfied with the category. On the dimension of empathy showed $86,4 \%$ of patients very satisfied. On the dimension of reliability showed $84,5 \%$ of patients very satisfied. On the dimension of responsiveness showed $84,1 \%$ of patients very satisfied. On the dimension of physical appearance showed $80,7 \%$ of patients very satisfied. On the dimension of medical services showed $89,1 \%$ of patients very satisfied. On the dimension of professionalism showed $91,6 \%$ of patients very satisfied. Based results of patient satisfaction with dental care in Bahu Health centers based on seven dimensions showed rate index $85,32 \%$ of patients very satisfied.
\end{abstract}

Keywords: Patient satisfaction, Dental care and oral.

\begin{abstract}
Abstrak: Kepuasan pasien terhadap pelayanan kesehatan gigi dan mulut merupakan perbandingan antara persepsi terhadap pelayanan yang diterima dengan harapannya sebelum mendapatkan pelayanan. Penelitian ini dilaksanakan di Puskesmas Bahu berdasarkan tujuh dimensi mutu pelayanan yaitu jaminan, empati, kehandalan, daya tanggap, tampilan fisik, pelayanan medis dan profesionalisme berdasarkan skala Likert. Jenis penelitian yaitu deskriptif dengan jumlah sampel 48 orang. Cara pengambilan sampel yaitu total sampling. Hasil penelitian menunjukkan kepuasan pasien terhadap dimensi jaminan sebesar $80,9 \%$ dengan kategori sangat puas. Pada dimensi empati menunjukkan 86,4\% pasien merasa sangat puas. Pada dimensi kehandalan menunjukkan 84,5\% pasien merasa sangat puas. Pada dimensi daya tanggap menunjukkan $84,1 \%$ pasien merasa sangat puas. Pada dimensi tampilan fisik menunjukkan 80,7\% pasien merasa sangat puas. Pada dimensi pelayanan medis menunjukkan 89,1\% pasien merasa sangat puas. Pada dimensi profesionalisme 91,6\% pasien merasa sangat puas. Berdasarkan hasil penelitian tentang kepuasan pasien terhadap perawatan gigi dan mulut di Puskesmas Bahu ditinjau dari dimensi pelayanan menunjukkan indeks rata-rata sebesar 85,32\% dengan kategori sangat puas.
\end{abstract}

Kata kunci: kepuasan pasien, perawatan gigi dan mulut. 
Berdasarkan UU Kesehatan No. 23 Tahun 1992, kesehatan adalah keadaan sejahtera dari badan, jiwa, dan sosial yang memungkinkan setiap orang hidup produktif secara sosial dan ekonomis. ${ }^{1}$ Dalam Program Pembangunan Nasional Indonesia, tujuan pembangunan kesehatan adalah mewujudkan Indonesia sehat pada tahun 2020. Dalam rangka mencapai tujuan tersebut dilakukan upaya kesehatan menyeluruh terpadu dan merata yang dapat di terima dan terjangkau oleh seluruh lapisan masyarakat dengan peran aktif dari masyarakat tersebut. Arahan ini mencakup bidang kesehatan gigi, bahwa upaya kesehatan gigi dan mulut dilaksanakan dengan memacu meningkatkan kemandirian masyarakat untuk menolong dirinya sendiri dalam memelihara kesehatan gigi. ${ }^{2}$

Perawatan gigi dan mulut bukan hanya untuk mengobati gigi sakit dan bermasalah, tapi juga untuk memperbaiki penampilan gigi yang pada akhirnya akan menciptakan rasa percaya diri yang tinggi. Seiring berjalannya waktu meningkatnya kesadaran akan pentingnya kesehatan gigi dan mulut akan menimbulkan kepuasan pada diri setiap pasien.

Kepuasan pasien terhadap pelayanan kesehatan gigi dan mulut adalah perbandingan antara persepsi terhadap pelayanan yang di terima dengan harapannya sebelum mendapatkan pelayanan. Apabila harapannya terpenuhi, berarti pelayanan tersebut telah memberikan suatu kualitas yang luar biasa dan juga akan menimbulkan kepuasan yang tinggi. ${ }^{1}$

Kebutuhan dan harapan terhadap pelayanan yang cepat dan tepat, biaya pengobatan yang murah, tenaga medis yang terampil serta sikap yang ramah dan komunikatif adalah sebagian dari tuntutan pasien. Namun hanya sebagian pelayanan kesehatan yang mampu memenuhi tuntutan tersebut. $^{3}$

Puskesmas Bahu merupakan salah satu puskesmas di kota Manado yang banyak di kunjungi oleh masyarakat oleh karena letaknya yang strategis dan tenaga kesehatan yang memadai. Namun dalam memberikan pelayanan masih banyak masyarakat/pasien yang mengeluh terhadap kinerja puskesmas seperti proses administrasi yang lambat sehingga harus menunggu dalam waktu yang cukup lama, kurangnya kebersihan puskesmas, serta peralatan yang kurang memadai. Berdasarkan hal tersebut maka peneliti ingin melakukan penelitian tentang kepuasan pasien terhadap perawatan gigi dan mulut di PuskesmasBahu.

\section{METODE PENELITIAN}

Jenis penelitian yang digunakan yaitu penelitian deskriptif dengan potong lintang (cross sectional studi). Penelitian ini telah dilaksanakan di Puskesmas Bahu Kecamatan Malalayang Kota Manado pada bulan Mei sampai dengan Juni tahun 2014. Populasi penelitian ini yaitu seluruh pasien perawatan Gigi dan Mulut di Puskesmas Bahu Kecamatan Malalayang Kota Manado yang hadir pada saat penelitian. Sampel penelitian ini menggunakan teknik total sampling. Bertujuan untuk mengambil sampel yaitu seluruh pasien yang datang melakukan perawatan Gigi dan Mulut di Puskesmas Bahu Kecamatan Malalayang Kota Manado pada bulan Mei sampai Juni 2014. Variabel penelitian yaitu kepuasan pasien dan perawatan gigi dan mulut. Definisi operasional yaitu kepuasan pasien berdasarkan dimensi pelayanan dan perawatan kesehatan gigi dan mulut. Instrumen penelitian yaitu alat tulis menulis dan kuisioner. Pengolahan dan analisis data diolah berdasarkan distribusi frekuensi dan disajikan dalam bentuk tabel.

\section{HASIL PENELITIAN}

Distribusi pasien yang melakukan perawatan gigi dan mulut di Puskesmas Bahu dimana pasien yang berjenis kelamin laki-laki berjumlah 25 orang atau sebesar $52 \%$, sedangkan pasien yang berjenis kelamin perempuan berjumlah 23 orang atau sebesar 48\% (Tabel 1).

Pada Tabel 2 dari 48 pasien yang melakukan perawatan gigi dan mulut di Puskesmas Bahu terdapat 5 (10,4\%) pasien dengan kelompok umur 15-20 tahun, 8 (16,6\%) dengan kelompok umur 21-30 
tahun, 13 (27\%) pasien dengan kelompok umur 31-40 tahun, 11 (23\%) pasien dengan kelompok umur 41-50 tahun, 9(18,8\%) pasien dengan kelompok umur 51-60 tahun, dan $2(4,2 \%)$ pasien dengan kelompok umur $>61$ tahun.

Tabel 1. Distribusi pasien yang melakukan perawatan gigi dan mulut menurut jenis kelamin

\begin{tabular}{ccc}
\hline & \multicolumn{2}{c}{ Banyaknya Pasien } \\
\cline { 2 - 3 } Jenis Kelamin & n & \% \\
\hline Laki-laki & 25 & 52 \\
Perempuan & 23 & 48 \\
Jumlah & 48 & 100 \\
\hline
\end{tabular}

Tabel 2. Distribusi pasien yang melakukan perawatan gigi dan mulut menurut kelompok umur

\begin{tabular}{ccc}
\hline & \multicolumn{2}{c}{ Banyaknya Pasien } \\
\cline { 2 - 3 } Kelompok Umur & $\mathrm{n}$ & $\%$ \\
\hline 15-20 tahun & 5 & 10,4 \\
21-30 tahun & 8 & 16,6 \\
31-40 tahun & 13 & 27 \\
41-50 tahun & 11 & 23 \\
51-60 tahun & 9 & 18,8 \\
> 61 tahun & 2 & 4,2 \\
Jumlah & 48 & 100 \\
\hline
\end{tabular}

Data pada Tabel 3 menunjukkan kepuasan pasien terhadap perawatan gigi dan mulut di tinjau dari dimensi pelayanan jaminan, dimana untuk kemampuan dokter gigi menangani keluhan pasien sebanyak $80,8 \%$ (46 orang memilih puas, 2 orang memilih sangat puas), penjelasan prosedur kerja sebanyak $81,6 \%$ (2 orang memilih cukup puas, 40 orang memilih puas, 6 orang memilih sangat puas), penjelasan hasil pemeriksaan sebanyak $80,8 \%$ (46 orang memilih puas, 2 orang memilih sangat puas), dan untuk kerahasiaan penyakit terjaga sebanyak $80,4 \%$ (47 orang memilih puas, 1 orang memilih sangat puas). Dari hasil tersebut diperoleh index rata-rata sebesar $80,9 \%$.

Berdasarkan Data pada Tabel 4, kepuasan pasien terhadap perawatan gigi dan mulut di tinjau dari dimensi pelayanan empati, dimana untuk sikap kesungguhan dokter gigi dalam menangani keluhan pasien sebanyak 87,9\% (29 orang memilih puas, 19 orang memilih sangat puas), dan perhatian dokter gigi dalam memberikan pelayanan sebanyak 85\% (36 orang memilih puas, 12 orang memilih sangat puas). Dari hasil tersebut diperoleh index rata-rata sebesar $86,4 \%$.

Tabel 3. Distribusi kepuasan pasien terhadap perawatan gigi dan mulut berdasarkan dimensi pelayanan jaminan

\begin{tabular}{|c|c|c|c|c|c|c|c|c|c|c|c|c|c|c|c|c|}
\hline \multirow{2}{*}{$\begin{array}{l}\text { Dimensi } \\
\text { Pelayanan } \\
\text { Jaminan }\end{array}$} & \multicolumn{5}{|c|}{ Pencabutan Gigi } & \multicolumn{5}{|c|}{ Penambalan Gigi } & \multicolumn{5}{|c|}{$\begin{array}{c}\text { Perawatan Penyakit } \\
\text { Mulut }\end{array}$} & \multirow[t]{2}{*}{$\begin{array}{c}\text { Index } \\
\%\end{array}$} \\
\hline & STP & $\mathrm{TP}$ & $\mathrm{CP}$ & $\mathrm{P}$ & SP & STP & TP & $\mathrm{CP}$ & $\mathrm{P}$ & SP & STP & TP & $\mathrm{CP}$ & $\mathrm{P}$ & SP & \\
\hline $\begin{array}{l}\text { Kemampuan } \\
\text { dokter gigi } \\
\text { menangani } \\
\text { keluhan pasien }\end{array}$ & - & - & - & 18 & 1 & - & - & - & 5 & 1 & - & - & - & 23 & - & 80,8 \\
\hline $\begin{array}{l}\text { Penjelasan } \\
\text { prosedur kerja }\end{array}$ & - & - & 2 & 16 & 1 & - & - & - & 4 & 2 & - & - & - & 20 & 3 & 81,6 \\
\hline $\begin{array}{l}\text { Penjelasan hasil } \\
\text { pemeriksaan }\end{array}$ & - & - & - & 19 & - & - & - & - & 5 & 1 & - & - & - & 22 & 1 & 80,8 \\
\hline $\begin{array}{c}\text { Kerahasiaan } \\
\text { penyakit terjaga }\end{array}$ & - & - & - & 19 & - & - & - & - & 6 & - & - & - & - & 22 & 1 & 80,4 \\
\hline Jumlah Pasien & & & 19 & & & & & 6 & & & & & 23 & & & $\begin{array}{l}\text { Rata- } \\
\text { rata: } \\
\mathbf{8 0 , 9}\end{array}$ \\
\hline
\end{tabular}


Jurnal e-GiGi (eG), Volume 2, Nomor 2, Juli-Desember 2014

Tabel 4. Distribusi kepuasan pasien terhadap perawatan gigi dan mulut berdasarkan dimensi pelayanan empati

\begin{tabular}{|c|c|c|c|c|c|c|c|c|c|c|c|c|c|c|c|c|}
\hline \multirow{2}{*}{$\begin{array}{l}\text { Dimensi } \\
\text { Pelayanan } \\
\text { Empati } \\
\end{array}$} & \multicolumn{5}{|c|}{ Pencabutan Gigi } & \multicolumn{5}{|c|}{ Penambalan Gigi } & \multicolumn{5}{|c|}{$\begin{array}{c}\text { Perawatan Penyakit } \\
\text { Mulut }\end{array}$} & \multirow[t]{2}{*}{$\underset{\%}{\operatorname{Index}}$} \\
\hline & STP & TP & CP & $\mathrm{P}$ & SP & STP & TP & CP & $\mathrm{P}$ & SP & STP & TP & CP & $\mathrm{P}$ & SP & \\
\hline Sikap & & & & & & & & & & & & & & & & \\
\hline $\begin{array}{l}\text { kesungguhan } \\
\text { dokter gigi } \\
\text { dalam } \\
\text { menangani } \\
\text { keluhan }\end{array}$ & - & - & - & 12 & 7 & - & - & - & 4 & 2 & - & - & - & 13 & 10 & 87,9 \\
\hline $\begin{array}{l}\text { Perhatian dokter } \\
\text { gigi dalam } \\
\text { memberikan }\end{array}$ & - & - & - & 13 & 6 & - & - & - & 4 & 2 & - & - & - & 19 & 4 & 85 \\
\hline $\begin{array}{l}\text { pelayanan } \\
\text { Jumlah Pasien }\end{array}$ & & & 19 & & & & & 6 & & & & & 23 & & & $\begin{array}{l}\text { Rata- } \\
\text { rata: } \\
\mathbf{8 6 , 4}\end{array}$ \\
\hline
\end{tabular}

Tabel 5. Distribusi kepuasan pasien terhadap perawatan gigi dan mulut berdasarkan dimensi pelayanan kehandalan

\begin{tabular}{|c|c|c|c|c|c|c|c|c|c|c|c|c|c|c|c|c|}
\hline \multirow{2}{*}{$\begin{array}{c}\text { Dimensi } \\
\text { Pelayanan } \\
\text { Kehandalan }\end{array}$} & \multicolumn{5}{|c|}{ Pencabutan Gigi } & \multicolumn{5}{|c|}{ Penambalan Gigi } & \multicolumn{5}{|c|}{$\begin{array}{c}\text { Perawatan Penyakit } \\
\text { Mulut }\end{array}$} & \multirow[t]{2}{*}{$\begin{array}{c}\text { Index } \\
\%\end{array}$} \\
\hline & STP & TP & CP & $\mathrm{P}$ & SP & STP & TP & CP & P SI & $\mathrm{P}$ & STP & TP & CP & $\mathrm{P}$ & SP & \\
\hline $\begin{array}{l}\text { Prosedur } \\
\text { pelayanan } \\
\text { administrasi }\end{array}$ & - & - & 2 & 16 & 1 & - & - & - & 6 & - & - & - & 2 & 18 & 3 & 80 \\
\hline $\begin{array}{l}\text { Sikap petugas } \\
\text { administrasi } \\
\text { Jam buka kartu }\end{array}$ & - & - & - & 18 & 1 & - & - & - & 5 & 1 & - & - & 1 & 20 & 2 & 81,2 \\
\hline $\begin{array}{l}\text { poliklinik gigi } \\
\text { Jam kedatangan }\end{array}$ & - & - & - & 14 & 5 & - & - & - & 4 & 2 & - & - & - & 13 & 10 & 87 \\
\hline $\begin{array}{l}\text { dokter gigi } \\
\text { Jumlah Pasien }\end{array}$ & - & - & 19 & 11 & 8 & - & - & $6^{-}$ & 3 & 3 & - & - & 23 & 10 & 13 & $\begin{array}{c}90 \\
\text { Rata- } \\
\text { rata: } \\
\mathbf{8 4 , 5}\end{array}$ \\
\hline
\end{tabular}

Tabel 6. Distribusi kepuasan pasien terhadap perawatan gigi dan mulut berdasarkan dimensi pelayanan daya tanggap

\begin{tabular}{|c|c|c|c|c|c|c|c|c|c|c|c|c|c|c|c|c|}
\hline \multirow{2}{*}{$\begin{array}{c}\text { Dimensi } \\
\text { Pelayanan } \\
\text { Daya Tanggap }\end{array}$} & \multicolumn{5}{|c|}{ Pencabutan Gigi } & \multicolumn{5}{|c|}{ Penambalan Gigi } & \multicolumn{5}{|c|}{$\begin{array}{c}\text { Perawatan Penyakit } \\
\text { Mulut }\end{array}$} & \multirow[t]{2}{*}{$\begin{array}{c}\text { Index } \\
\%\end{array}$} \\
\hline & STP & TP & CP & $\mathrm{P}$ & SP & STP & $\mathrm{TP}$ & $\mathrm{CP}$ & $\mathrm{P}$ & $\mathrm{P}$ & STP & $\mathrm{TP}$ & $\mathrm{CP}$ & $\mathrm{P}$ & SP & \\
\hline $\begin{array}{l}\text { Kecepatan dokter gigi } \\
\text { menangani keluhan } \\
\text { pasien }\end{array}$ & - & - & - & 16 & 3 & - & - & - & 4 & 2 & - & - & - & 19 & 4 & 83,7 \\
\hline $\begin{array}{l}\text { Kejelasan memberikan } \\
\text { informasi penyakit }\end{array}$ & - & - & - & 14 & 5 & - & - & - & 3 & 3 & - & - & - & 19 & 4 & 85 \\
\hline $\begin{array}{l}\text { Kejelasan memberikan } \\
\text { instruksi sebelum dan } \\
\text { sesudah perawatan }\end{array}$ & - & - & - & 15 & 4 & - & - & - & 5 & 1 & - & - & - & 19 & 4 & 83,7 \\
\hline Jumlah Pasien & & & 19 & & & & & 6 & & & & & 23 & & & $\begin{array}{l}\text { Rata- } \\
\text { rata: } \\
\mathbf{8 4 , 1}\end{array}$ \\
\hline
\end{tabular}


Sembel, Opod, Hutagalung; Gambaran Tingkat Kepuasan Pasien...

Tabel 7. Distribusi kepuasan pasien terhadap perawatan gigi dan mulut berdasarkan dimensi pelayanan tampilan fisik

\begin{tabular}{|c|c|c|c|c|c|c|c|c|c|c|c|c|c|c|c|c|}
\hline \multirow{2}{*}{$\begin{array}{l}\text { Dimensi } \\
\text { Pelayanan } \\
\text { Tampilan Fisik }\end{array}$} & \multicolumn{5}{|c|}{ Pencabutan Gigi } & \multicolumn{5}{|c|}{ Penambalan Gigi } & \multicolumn{5}{|c|}{$\begin{array}{c}\text { Perawatan Penyakit } \\
\text { Mulut }\end{array}$} & \multirow[t]{2}{*}{$\begin{array}{c}\text { Index } \\
\%\end{array}$} \\
\hline & STP & $\mathrm{TP}$ & $\mathrm{CP}$ & $\mathrm{P}$ & SP & STP & $\mathrm{TP}$ & $\mathrm{CP}$ & $\mathrm{PSS}$ & SP & STP & $\mathrm{TP}$ & $\mathrm{CP}$ & $\mathrm{P}$ & SP & \\
\hline $\begin{array}{l}\text { Penampilan } \\
\text { dokter gigi } \\
\text { Kebersihan dan }\end{array}$ & - & - & - & 18 & 1 & - & - & - & 5 & 1 & - & - & - & 21 & 2 & 81,6 \\
\hline $\begin{array}{l}\text { kerapian ruang } \\
\text { perawatan }\end{array}$ & - & - & - & 17 & 2 & - & - & - & 5 & 1 & - & - & - & 21 & 2 & 82 \\
\hline $\begin{array}{l}\text { Kebersihan ruang } \\
\text { tunggu } \\
\text { Kebersihan }\end{array}$ & - & - & 3 & 16 & - & - & - & 1 & 4 & 1 & - & - & 2 & 20 & 1 & 78,3 \\
\hline & & & 2 & 16 & 1 & - & - & - & 5 & 1 & - & - & - & 22 & 1 & 80,4 \\
\hline $\begin{array}{l}\text { peralatan } \\
\text { Jumlah Pasien }\end{array}$ & - & - & 19 & 17 & 2 & - & - & $6^{-}$ & 6 & - & - & - & $\begin{array}{r}1 \\
23\end{array}$ & 20 & 2 & $\begin{array}{r}81,2 \\
\text { Rata- } \\
\text { rata: } \\
\mathbf{8 0 , 7}\end{array}$ \\
\hline
\end{tabular}

Tabel 8. Distribusi kepuasan pasien terhadap perawatan gigi dan mulut berdasarkan dimensi pelayanan pelayanan medis

\begin{tabular}{|c|c|c|c|c|c|c|c|c|c|c|c|c|c|c|c|c|}
\hline \multirow{2}{*}{$\begin{array}{l}\text { Dimensi } \\
\text { Pelayanan } \\
\text { Medis }\end{array}$} & \multicolumn{5}{|c|}{ Pencabutan Gigi } & \multicolumn{5}{|c|}{ Penambalan Gigi } & \multicolumn{5}{|c|}{$\begin{array}{c}\text { Perawatan Penyakit } \\
\text { Mulut }\end{array}$} & \multirow[t]{2}{*}{$\begin{array}{c}\text { Index } \\
\%\end{array}$} \\
\hline & STP & TP & $\mathrm{CP}$ & $\mathrm{P}$ & SP & STP & $\mathrm{TP}$ & $\mathrm{CP}$ & $\mathrm{P}$ & SP & STP & TP & CP & $\mathrm{P}$ & SP & \\
\hline $\begin{array}{l}\text { Efektifitas } \\
\text { pelayanan }\end{array}$ & - & - & 1 & 15 & 3 & - & - & - & 4 & 2 & - & - & - & 14 & 9 & 85,4 \\
\hline $\begin{array}{l}\text { Manfaat } \\
\text { pelayanan yang } \\
\text { diberikan pada } \\
\text { pasien }\end{array}$ & - & - & 10 & 8 & 11 & - & - & - & 1 & 5 & - & - & 23 & 8 & 15 & $\begin{array}{r}92,9 \\
\text { Rata- } \\
\text { rata: } \\
\mathbf{8 0 1} 1\end{array}$ \\
\hline
\end{tabular}

Tabel 9. Distribusi kepuasan pasien terhadap perawatan gigi dan mulut berdasarkan dimensi pelayanan profesionalisme

\begin{tabular}{|c|c|c|c|c|c|c|c|c|c|c|c|c|c|c|c|c|}
\hline \multirow{2}{*}{$\begin{array}{l}\text { Dimensi } \\
\text { Pelayanan } \\
\text { Profesionalisme }\end{array}$} & \multicolumn{5}{|c|}{ Pencabutan Gigi } & \multicolumn{5}{|c|}{ Penambalan Gigi } & \multicolumn{5}{|c|}{$\begin{array}{c}\text { Perawatan Penyakit } \\
\text { Mulut }\end{array}$} & \multirow[t]{2}{*}{$\begin{array}{c}\text { Index } \\
\%\end{array}$} \\
\hline & STP & TP & $\mathrm{CP}$ & $\mathrm{P}$ & SP & STP & $\mathrm{TP}$ & $\mathrm{CP}$ & $\mathrm{P}$ & SP & STP & TP & $\mathrm{CP}$ & $\mathrm{P}$ & SP & \\
\hline $\begin{array}{c}\text { Keahlian dan } \\
\text { pengalaman } \\
\text { dokter gigi }\end{array}$ & - & - & 1 & 4 & 14 & - & - & - & 1 & 5 & - & - & - & 10 & 13 & 92,9 \\
\hline $\begin{array}{l}\text { Pengetahuan dokter } \\
\text { gigi mendiagnosa } \\
\text { penyakit dan } \\
\text { memberikan } \\
\text { perawatan }\end{array}$ & - & - & - & 5 & 14 & - & - & - & 4 & 2 & - & - & - & 14 & 9 & $\begin{array}{l}90,4 \\
\text { Rata- } \\
\text { rata: }\end{array}$ \\
\hline
\end{tabular}

Data pada Tabel 5 menunjukkan kepuasan pasien terhadap perawatan gigi dan mulut di tinjau dari dimensi pelayanan kehandalan, dimana untuk prosedur pelayanan administrasi sebanyak $80 \%$ (4 orang memilih cukup puas, 40 orang memilih puas, 4 orang memilih sangat puas), sikap petugas administrasi sebanyak 81,2\% (1 orang memilih cukup puas, 43 orang memilih puas, 4 orang memilih sangat puas), jam buka kartu poliklinik gigi sebanyak $87 \%$ (31 orang memilih puas, 17 
orang memilih sangat puas), dan jam kedatangan dokter gigi sebanyak 90\% (24 orang memilih puas, 24 orang memilih sangat puas). Dari hasil tersebut diperoleh index rata-rata sebesar $84,5 \%$.

Data pada Tabel 6 menunjukkan kepuasan pasien terhadap perawatan gigi dan mulut di tinjau dari dimensi pelayanan daya tanggap, dimana kecepatan dokter gigi menangani keluhan pasien sebanyak 83,7\% (39 orang memilih puas, 9 orang memilih sangat puas), kejelasan memberikan informasi penyakit sebanyak 85\% (36 orang memilih puas, 12 orang memilih sangat puas), dan kejelasan memberikan instruksi sebelum dan sesudah perawatan sebanyak 83,7\% (39 orang memilih puas, 9 orang memilih sangat puas). Dari hasil tersebut diperoleh index rata-rata sebesar 84,1\%.

Berdasarkan Data pada Tabel 7 kepuasan pasien terhadap perawatan gigi dan mulut di tinjau dari dimensi pelayanan tampilan fisik, dimana penampilan dokter gigi sebanyak $81,6 \%$ (44 orang memilih puas, 4 orang memilih sangat puas), kebersihan dan kerapian ruang perawatan sebanyak $82 \%$ (43 orang memilih puas, 5 orang memilih sangat puas), kebersihan ruang tunggu sebanyak $78,3 \%$ (6 orang memilih cukup puas, 40 orang memilih puas, 2 orang memilih sangat puas), kebersihan peralatan sebanyak 80,4\% (2 orang memilih cukup puas, 43 orang memilih puas, 3 orang memilih sangat puas) dan kelengkapan peralatan sebanyak 81,2\% (1 orang memilih cukup puas, 43 orang memilih puas, 4 orang memilih sangat puas). Dari hasil tersebut diperoleh index rata-rata sebesar $80,7 \%$.

Berdasarkan data pada Tabel 8, kepuasan pasien terhadap perawatan gigi dan mulut di tinjau dari dimensi pelayanan yaitu pelayanan medis, dimana efektifitas pelayanan sebanyak $85,4 \%$ (1 orang memilih cukup puas, 33 orang memilih puas, 14 orang memilih sangat puas), dan manfaat pelayanan yang diberikan pada pasien sebanyak 92,9\% (17 orang memilih puas, 31 orang memilih sangat puas). Dari hasil tersebut diperoleh index rata-rata sebesar $89,1 \%$.
Berdasarkan data pada Tabel 9, kepuasan pasien terhadap perawatan gigi dan mulut di tinjau dari dimensi pelayanan profesionalisme, dimana keahlian dan pengalaman dokter gigi sebanyak 92,9\% (1 orang memilih cukup puas, 15 orang memilih puas, 32 orang memilih sangat puas), pengetahuan dokter gigi mendiagnosa penyakit dan memberikan perawatan sebanyak 90,4\% (23 orang memilih puas, 25 orang memilih sangat puas). Dari hasil tersebut diperoleh index rata-rata sebesar $91,6 \%$.

\section{BAHASAN}

Kepuasan pasien yaitu keadaan saat keinginan, harapan dan kebutuhan pasien dapat dipenuhi. ${ }^{4}$ Gambaran hasil penelitian menunjukkan bahwa pasien yang lebih banyak melakukan perawatan gigi dan mulut di Puskesmas Bahu berjenis kelamin laki-laki yaitu 25 (52\%) pasien, sedangkan jenis kelamin perempuan sebanyak 23 (48\%) pasien. Hal ini sesuai dengan penelitian Haydar Sur pada tahun 2004 dan Suhamiarti pada tahun 2007 yang menyatakan bahwa laki-laki mudah merasa puas terhadap perawatan gigi dan mulut sehingga mereka yang lebih banyak melakukan perawatan gigi dan mulut di Puskesmas Bahu. ${ }^{3}$ Kelompok umur pasien yang paling banyak melakukan perawatan gigi dan mulut di Puskesmas Bahu yaitu umur antara 31-40 tahun dengan 13 pasien atau sebesar $27 \%$ dan diikuti kelompok umur antara 41-50 tahun dengan 11 pasien atau sebesar 23\% sedangkan kelompok umur yang paling sedikit melakukan perawatan gigi dan mulut terdapat pada umur $>61$ tahun dengan 2 pasien atau sebesar 4,2\%. Pada penelitian yang dilakukan Ramadanura pada tahun 2002 menunjukkan bahwa golongan umur muda (31-40 tahun) mudah merasa puas. ${ }^{3}$ Hal ini sesuai dengan hasil penelitian yang menunjukkan bahwa kelompok umur 31-40 tahun yang lebih banyak melakukan perawatan gigi dan mulut di Puskesmas Bahu. 
Distribusi kepuasan pasien terhadap perawatan gigi dan mulut berdasarkan dimensi pelayanan jaminan ditinjau dari kemampuan dokter gigi menangani keluhan pasien menunjukkan index sebesar $80,8 \%$ dengan kategori sangat puas. ${ }^{5}$ Pada penelitian ini pasien merasa sangat puas terhadap kemampuan dokter gigi dalam menangani setiap keluhan yang disampaikan pasien sehingga pada tindakan pencabutan gigi, penambalan, dan perawatan penyakit mulut pasien merasa sangat puas.

Selanjutnya dimensi pelayanan jaminan ditinjau dari penjelasan prosedur kerja menunjukkan index sebesar 81,6\% dengan kategori sangat puas. ${ }^{5}$ Pada penelitian ini pasien merasa sangat puas terhadap penjelasan prosedur kerja yang disampaikan dokter dan perawat gigi sebelum melakukan perawatan sehingga pasien telah mengetahui terlebih dahulu segala prosedur yang akan dilakukan. Hal ini yang mengakibatkan pasien merasa sangat puas terhadap pelayanan tersebut.

Pada dimensi pelayanan jaminan ditinjau dari penjelasan hasil pemeriksaan menunjukkan index sebesar 80,8\% dengan kategori sangat puas. $^{5}$ Penjelasan hasil pemeriksaan oleh petugas kesehatan gigi merupakan keinginan pasien yang penting. Dengan penjelasan hasil pemeriksaan tersebut pasien bisa mengetahui tentang masalah kesehatan gigi dan mulutnya sendiri dan berharap masalah tersebut bisa ditangani oleh petugas kesehatan gigi yang ada di poliklinik gigi tersebut. Pada penelitian ini pasien merasa sangat puas terhadap penjelasan hasil pemeriksaan yang disampaikan oleh petugas kesehatan gigi di Puskesmas Bahu.

Selanjutnya dimensi pelayanan jaminan ditinjau dari kerahasiaan penyakit terjaga menunjukkan index sebesar $80,4 \%$ dengan kategori sangat puas. $^{5}$ Pada penelitian ini pasien merasa bahwa penyakit atau masalah kesehatan gigi dan mulutnya bisa dirahasiakan oleh petugas kesehatan gigi yang ada di poliklinik gigi tersebut. Oleh karena itu pasien merasa sangat puas terhadap pelayanan tersebut.
Keterampilan komunikasi antara dokter gigi dan pasien, memberi informasi terhadap perawatan yang akan diberikan, care atau perhatian terhadap keluhan yang diutarakan pasien merupakan hal yang paling penting dalam menentukan kepuasan pasien. ${ }^{4}$ Dari hasil penelitian kepuasan pasien berdasarkan dimensi pelayanan jaminan (Assurance) diperoleh index rata-rata sebesar 80,9\% dengan kategori sangat puas. ${ }^{5}$ Hal ini sesuai dengan hasil penelitian Simbolon pada tahun 2011 yang menunjukkan kepuasan pasien terhadap dimensi pelayanan jaminan sebesar 98\%. ${ }^{3}$ Hal ini disebabkan karena dokter dan perawat gigi telah memberikan pelayanan yang sangat baik sehingga menimbulkan rasa aman pada pasien yang menyebabkan pasien merasa puas terhadap pelayanan yang diberikan.

Distribusi kepuasan pasien terhadap perawatan gigi dan mulut berdasarkan dimensi pelayanan empati ditinjau dari sikap kesungguhan dokter gigi menangani keluhan pasien menunjukkan index sebesar 87,9\% dengan kategori sangat puas. ${ }^{5}$ Pada penelitian ini sikap kesungguhan dokter gigi menangani keluhan pasien merupakan hal yang penting. Dengan sikap tersebut pasien merasa bahwa masalah kesehatan gigi dan mulutnya bisa ditangani oleh dokter gigi tersebut. Hal ini yang membuat pasien merasa sangat puas terhadap sikap empati yang diberikan dokter gigi kepadanya untuk mengatasi keluhan yang disampaikan.

Berdasarkan dimensi pelayanan empati ditinjau dari perhatian dokter gigi dalam memberikan pelayanan menunjukkan index sebesar $85 \%$ dengan kategori sangat puas. ${ }^{5}$ Pada penelitian ini pasien yang melakukan perawatan gigi dan mulut merasa sangat puas terhadap perhatian dokter gigi dalam memberikan pelayanan, karena perhatian tersebut membuat pasien merasa bahwa dokter gigi telah memberikan perhatian yang tulus kepada mereka dan telah berusaha untuk mengatasi masalah kesehatan gigi dan mulut yang mereka sampaikan.

Dalam melakukan suatu perawatan dokter gigi harus memperhatikan kualitas pelayanan, kompetensi teknis, serta kepribadian dan sikap dokter gigi terhadap 
pasien. $^{4}$ Dari hasil penelitian kepuasan pasien berdasarkan dimensi pelayanan empati (Empathy) diperoleh index rata-rata sebesar $86,4 \%$ dengan kategori sangat puas. ${ }^{5}$ Hal ini sesuai dengan penelitian Simbolon pada tahun 2011 yang menunjukkan kepuasan pasien terhadap dimensi empati sebesar 66,7\%. ${ }^{3}$ Hal ini disebabkan karena dokter gigi telah memberikan perhatian dan sikap peduli yang tulus terhadap keluhan yang disampaikan pasien yang pada akhirnya menimbulkan kepuasan pasien terhadap pelayanan tersebut.

Distribusi kepuasan pasien terhadap perawatan gigi dan mulut berdasarkan dimensi pelayanan kehandalan ditinjau dari prosedur pelayanan administrasi menunjukkan index sebesar 80\% dengan kategori puas. ${ }^{5}$ Pada penelitian ini terdapat beberapa pasien yang mengatakan puas dan sangat puas terhadap prosedur administrasi yang ada di Puskesmas Bahu tetapi ada juga yang mengatakan cukup puas. Hal ini disebabkan karena ada beberapa pasien pengguna Askes dan Jamkesmas yang melakukan perawatan gigi dan mulut di Puskesmas Bahu dan mereka merasa bahwa prosedur administrasi disana cukup rumit. Hal ini yang membuat mereka tidak terlalu puas terhadap pelayanan tersebut.

Selanjutnya dimensi pelayanan kehandalan ditinjau dari sikap petugas administrasi menunjukkan index sebesar 81,2\% dengan kategori puas. $^{5}$ Pada penelitian ini secara umum pasien merasa puas dan sangat puas terhadap sikap petugas administrasi yang ada di Puskesmas Bahu. Tetapi ada satu pasien yang mengatakan cukup puas terhadap sikap petugas administrasi tersebut.

Pada dimensi pelayanan kehandalan ditinjau dari jam buka kartu poliklinik gigi menunjukkan index sebesar $87 \%$ dengan kategori sangat puas. ${ }^{5}$ Pada penelitian ini pasien merasa sangat puas terhadap jam buka kartu poliklinik gigi yang ada di Puskesmas Bahu oleh karena jam buka kartu yang ada di poliklinik gigi tersebut tepat waktu.

Selanjutnya pada dimensi pelayanan kehandalan ditinjau dari jam kedatangan dokter gigi menunjukkan index sebesar $90 \%$ dengan kategori sangat puas. ${ }^{5}$ Pada penelitian ini pasien merasa sangat puas terhadap jam kedatangan dokter gigi di poliklinik gigi Puskesmas Bahu karena dokter gigi tersebut selalu datang tepat waktu sehingga pasien tidak akan menunggu kedatangan dokter gigi tersebut.

Dalam melakukan suatu tindakan dokter gigi harus melakukannya dengan kinerja yang sesuai dengan harapan pasien yang berarti ketepatan waktu, pelayanan yang sama untuk semua pasien, sikap yang simpatik dan dengan akurasi yang tinggi. Dari hasil penelitian kepuasan pasien berdasarkan dimensi pelayanan kehandalan (Reliability) diperoleh index rata-rata sebesar 84,5\% dengan kategori sangat puas. ${ }^{5}$ Berbeda dengan hasil penelitian Tri Sarmeilia tahun 2009 yang menunjukkan bahwa kepuasan pasien terhadap dimensi reliability sebesar 57,14\%, hal ini disebabkan karena pasien merasa kurang puas terhadap prosedur administrasi dan jam buka kartu yang ada disana. ${ }^{6}$

Distribusi kepuasan pasien terhadap perawatan gigi dan mulut berdasarkan dimensi pelayanan daya tanggap ditinjau dari kecepatan dokter gigi menangani keluhan pasien menunjukkan index sebesar $83,7 \%$ dengan kategori sangat puas. ${ }^{5}$ Pada penelitian ini pasien merasa sangat puas terhadap kecepatan dokter gigi menangani keluhan pasien karena dengan tindakan tersebut pasien merasa bahwa keluhannya bisa segera diatasi oleh dokter gigi tersebut.

Selanjutnya pada dimensi pelayanan daya tanggap ditinjau dari kejelasan memberikan informasi tentang penyakit menunjukkan index sebesar 85\% dengan kategori sangat puas. ${ }^{5}$ Pada penelitian ini pasien merasa sangat puas terhadap kejelasan informasi tentang penyakit yang disampaikan oleh dokter gigi yang ada di poliklinik gigi tersebut oleh karena penjelasan tentang informasi penyakit membuat pasien bisa mengetahui masalah kesehatan gigi dan mulutnya.

Pada dimensi pelayanan daya tanggap ditinjau dari kejelasan memberikan instruksi sebelum dan sesudah perawatan menunjuk- 
kan index sebesar 83,7\% dengan kategori sangat puas. $^{5}$ Kejelasan memberikan instruksi sebelum dan sesudah perawatan merupakan hal yang penting dan hal ini bisa menentukan keberhasilan suatu perawatan. Pada penelitian ini pasien merasa sangat puas terhadap kejelasan memberikan instruksi sebelum dan sesudah perawatan yang disampaikan dokter gigi oleh karena penjelasan tersebut membuat pasien merasa nyaman terhadap perawatan yang diberikan.

Faktor personal contohnya seperti keterampilan komunikasi antara dokter gigi dengan pasien dan memberi informasi terhadap perawatan yang akan diberikan merupakan hal yang paling penting dalam menentukan kepuasan pasien. ${ }^{4}$ Dari hasil penelitian kepuasan pasien berdasarkan dimensi pelayanan daya tanggap (Responsiveness) diperoleh index rata-rata sebesar $84,1 \%$ dengan kategori sangat puas. ${ }^{5}$ Berbeda dengan penelitian Gatu Shanti Aji Dewi tahun 2010 menunjukkan bahwa kepuasan pasien berdasarkan dimensi responsiveness sebesar 46,30\%, hal ini disebabkan karena pasien merasa kurang puas terhadap kecepatan tenaga medis pada saat pasien membutuhkan dan pemberian informasi yang kurang jelas. ${ }^{7}$

Distribusi kepuasan pasien terhadap perawatan gigi dan mulut berdasarkan dimensi pelayanan tampilan fisik ditinjau dari penampilan dokter gigi menunjukkan index sebesar 81,6\% dengan kategori sangat puas. ${ }^{5}$ Pada penelitian ini pasien merasa sangat puas terhadap penampilan dokter gigi yang ada di Puskesmas Bahu.

Pada dimensi pelayanan tampilan fisik ditinjau dari kebersihan dan kerapian ruang perawatan menunjukkan index sebesar $82 \%$ dengan kategori sangat puas. ${ }^{5}$ Pada penelitian ini pasien mengatakan sangat puas terhadap kebersihan dan kerapian ruang perawatan. Hal ini disebabkan karena ruang perawatan yang ada di poliklinik gigi Puskesmas Bahu diatur dengan rapi dan bersih sehingga pasien merasa sangat puas terhadap kebersihan dan kerapian ruang perawatan yang ada disana.

Pada dimensi pelayanan tampilan fisik ditinjau dari kebersihan ruang tunggu menunjukkan index sebesar 78,3\% dengan kategori puas. ${ }^{5}$ Pada penelitian ini ada pasien yang mengatakan puas dan sangat puas, tetapi ada juga beberapa pasien yang mengatakan cukup puas terhadap kebersihan ruang tunggu yang ada di poliklinik gigi Puskesmas Bahu. Hal ini disebabkan karena ruang tunggu yang ada disana berada di ruangan terbuka yang seringkali dicemari oleh polusi udara sehingga pasien hanya merasa cukup puas terhadap kebersihan ruang tunggu tersebut.

Pada dimensi pelayanan tampilan fisik ditinjau dari kebersihan peralatan menunjukkan index sebesar 80,4\% dengan kategori sangat puas. ${ }^{5}$ Pada penelitian ini pasien merasa puas dan sangat puas terhadap kebersihan peralatan yang ada di poliklinik gigi Puskesmas Bahu, tetapi ada juga beberapa yang mengatakan cukup puas. Hal ini disebabkan karena pasien melihat bahwa peralatan tersebut hanya dibersihkan dengan desinfektan dan tidak di sterilkan dengan alat sterilisasi.

Selanjutnya pada dimensi pelayanan tampilan fisik ditinjau dari kelengkapan peralatan menunjukkan index sebesar $81,2 \%$ dengan kategori sangat puas. $^{5}$ Pada penelitian ini pasien merasa puas dan sangat puas terhadap kelengkapan peralatan yang ada disana, akan tetapi ada satu pasien yang mengatakan cukup puas. Hal ini disebabkan karena pasien tersebut melihat bahwa tidak semua tindakan perawatan gigi dan mulut bisa dilakukan di Puskesmas Bahu oleh karena peralatannya yang belum terlalu lengkap sehingga Ia hanya mengatakan cukup puas terhadap kelengkapan peralatan yang ada disana.

Meskipun dianggap tidak sama pentingnya dengan faktor-faktor lain namun fasilitas seperti kerapihan, kenyamanan, kebersihan dari tempat praktek atau klinik dokter gigi itu sangat mempengaruhi kepuasan pasien. ${ }^{4}$ Dari hasil penelitian kepuasan pasien berdasarkan dimensi pelayanan tampilan fisik (Tangible) diperoleh index rata-rata sebesar 80,7\% dengan kategori sangat puas. ${ }^{5}$ Hal ini sesuai dengan penelitian Tri Sarmeilia tahun 2009 yang menunjukkan bahwa kepuasan pasien 
berdasarkan dimensi tangibles sebesar 68,57\%. ${ }^{6}$ Hal ini disebabkan karena pasien merasa puas terhadap fasilitas pelayanan di tempat tersebut sehingga mereka merasa nyaman untuk melakukan perawatan gigi dan mulut di Puskesmas Bahu.

Distribusi kepuasan pasien berdasarkan dimensi pelayanan medis ditinjau dari efektifitas pelayanan menunjukkanindex sebesar $85,4 \%$ dengan kategori sangat puas. ${ }^{5}$ Pada penelitian ini pasien merasa puas dan sangat puas terhadap efektifitas pelayanan yang ada di poliklinik gigi Puskesmas Bahu tetapi ada satu pasien yang mengatakan cukup puas. Hal ini disebabkan karena Ia merasa bahwa pelayanan tersebut kurang efektif oleh karena waktu pelayanannya kurang maksimal sehingga Ia hanya mengatakan cukup puas terhadap pelayanan tersebut.

Selanjutnya dimensi pelayanan medis ditinjau dari manfaat pelayanan yang diberikan pada pasien menunjukkan index sebesar 92,9\% dengan kategori sangat puas. ${ }^{5}$ Pada penelitian ini pasien merasa puas dan sangat puas terhadap manfaat pelayanan yang diberikan pada pasien. Hal ini disebabkan karena dokter dan perawat gigi telah memberikan pelayanan yang sangat baik kepada pasien sehingga pasien merasakan manfaat yang sangat banyak terhadap pelayanan yang diberikan.

Pelayanan medis yaitu berkaitan dengan aspek inti dari pelayanan medis seperti kelayakan, efektifitas dan manfaat pelayanan untuk pasien. Dari hasil penelitian kepuasan pasien berdasarkan dimensi pelayanan medis (Core medical service) diperoleh index rata-rata sebesar 89,1\% dengan kategori sangat puas. ${ }^{5}$ Berbeda dengan penelitian yang dilakukan Simbolon pada tahun 2011 menunjukkan bahwa kepuasan pasien terhadap dimensi pelayanan medis sebesar 54\%, hal ini disebabkan karena pasien kurang puas terhadap perawatan yang kurang lengkap di poliklinik gigi tersebut. $^{3}$

Distribusi kepuasan pasien terhadap perawatan gigi dan mulut berdasarkan dimensi pelayanan profesionalisme ditinjau dari keahlian dan pengalaman dokter gigi menunjukkan index sebesar 92,9\% dengan kategori sangat puas. $^{5}$ Pada penelitian tersebut pasien merasa puas dan sangat puas terhadap keahlian dan pengalaman dokter gigi namun ada satu pasien yang mengatakan cukup puas.

Pada dimensi pelayanan profesionalisme ditinjau dari pengetahuan dokter gigi mendiagnosa penyakit dan memberikan perawatan menunjukkan index sebesar 90,4\% dengan kategori sangat puas. ${ }^{5}$ Pada penelitian ini pasien merasa puas dan sangat puas terhadap pengetahuan dokter gigi mendiagnosa penyakit dan memberikan perawatan. Hal ini disebabkan karena pasien merasa dokter gigi telah mendiagnosa penyakitnya dengan benar dan telah memberikan perawatan yang baik sehingga mereka merasa sangat puas terhadap pelayanan tersebut.

Kompetensi teknis merupakan penentu utama atau sebagai determinan dari kepuasan pasien dilihat bagaimana keahlian operator atau dokter gigi dalam melakukan perawatan kepada pasien. Hal ini merupakan kombinasi dari ilmu yang telah diperoleh operator dengan praktek. ${ }^{4}$ Dari hasil penelitian kepuasan pasien berdasarkan dimensi pelayanan profesionalisme (Professionalism) diperoleh index rata-rata sebesar $91,6 \%$ dengan kategori sangat puas. ${ }^{5}$ Dari hasil penelitian Simbolon pada tahun 2011 menunjukkan bahwa kepuasan pasien terhadap dimensi profesionalisme sebesar $65,3 \% .^{3}$ Hal ini disebabkan karena pasien merasa bahwa dokter gigi memiliki keahlian dan pengalaman dalam merawat pasien sehingga pasien merasa puas terhadap perawatan di Puskemas tersebut.

Berdasarkan hasil penelitian tentang kepuasan pasien terhadap perawatan gigi dan mulut di Puskesmas Bahu ditinjau dari dimensi pelayanan diperoleh index rata-rata sebesar $85,32 \%$ dengan kategori sangat puas. $^{5}$

\section{SIMPULAN}

1. Unsur pelayanan jaminan dengan index rata-rata sebesar $80,9 \%$ pasien sangat puas. 
2. Unsur pelayanan empati dengan index rata-rata sebesar $86,4 \%$ pasien sangat puas.

3. Unsur pelayanan kehandalan dengan index rata-rata sebesar $84,5 \%$ pasien sangat puas.

4. Unsur pelayanan daya tanggap dengan index rata-rata sebesar $84,1 \%$ pasien sangat puas.

5. Unsur pelayanan tampilan fisik dengan index rata-rata sebesar $80,7 \%$ pasien sangat puas.

6. Unsur pelayanan medis dengan index rata-rata sebesar $89,1 \%$ pasien sangat puas.

7. Unsur pelayanan profesionalisme dengan index rata-rata sebesar 91,6\% pasien sangat puas.

\section{DAFTAR PUSTAKA}

1. Teguh, M. Tingkat Kepuasan Masyarakat Pulau Kodingareng terhadap Pelayanan Kesehatan Gigi dan Mulut. Makassar: Skripsi Fakultas Kedokteran Gigi Universitas Hassanudin; 2012. h. 1-4.

2. Aly, A. R. Hubungan Karakteristik Pasien dengan Tingkat Kepuasan terhadap Pelayanan di Poli Gigi dan Mulut Rumah
Sakit Umum Daerah Dr. Saiful Anwar Malang. Malang: Jurnal Manajemen Pelayanan Kesehatan. vol.09 No.04; 2006. h. $177-184$.

3. Simbolon, R. Tingkat Kepuasan Pasien Terhadap Pelayanan Kesehatan Gigi dan Mulut di RSUD DR. Djasamen Saragih Pematangsiantar. Sumatera Utara: Skripsi Fakultas Kedokteran Gigi Universitas Sumatera Utara; 2011. h. 1-19.

4. Azhari, A. Tingkat Kepuasan Pasien Pasca Pencabutan Gigi di RSGMP Kandea FKG UH Tahun 2013. Makassar: Skripsi Fakultas Kedokteran Gigi Universitas Hasanudin; 2013. h. 15-17.

5. Natsir, F. Artikel cara menghitung skala likert. [online] 2013 [cited 2014 Apr 08]; [5 screens]. Availble from: http://wordpress.com//cara-menghitungskala-likert/.

6. Sarmeilia, T. Tingkat Kepuasan Pasien Jamkesmas Terhadap Pelayanan Keperawatan di RSUD Kota Langsa. Sumatera Utara: Jurnal ilmiah Universitas Sumatera Utara; 2009. hal.1.

7. Dewi, G. S. A. Analisis Tingkat Kepuasan Pasien Terhadap Kualitas Pelayanan Jasa Pada Rumah Sakit Islam Surakarta. Surakarta: Jurnal Ilmiah Universitas Sebelas Maret; 2010. hal. 1. 